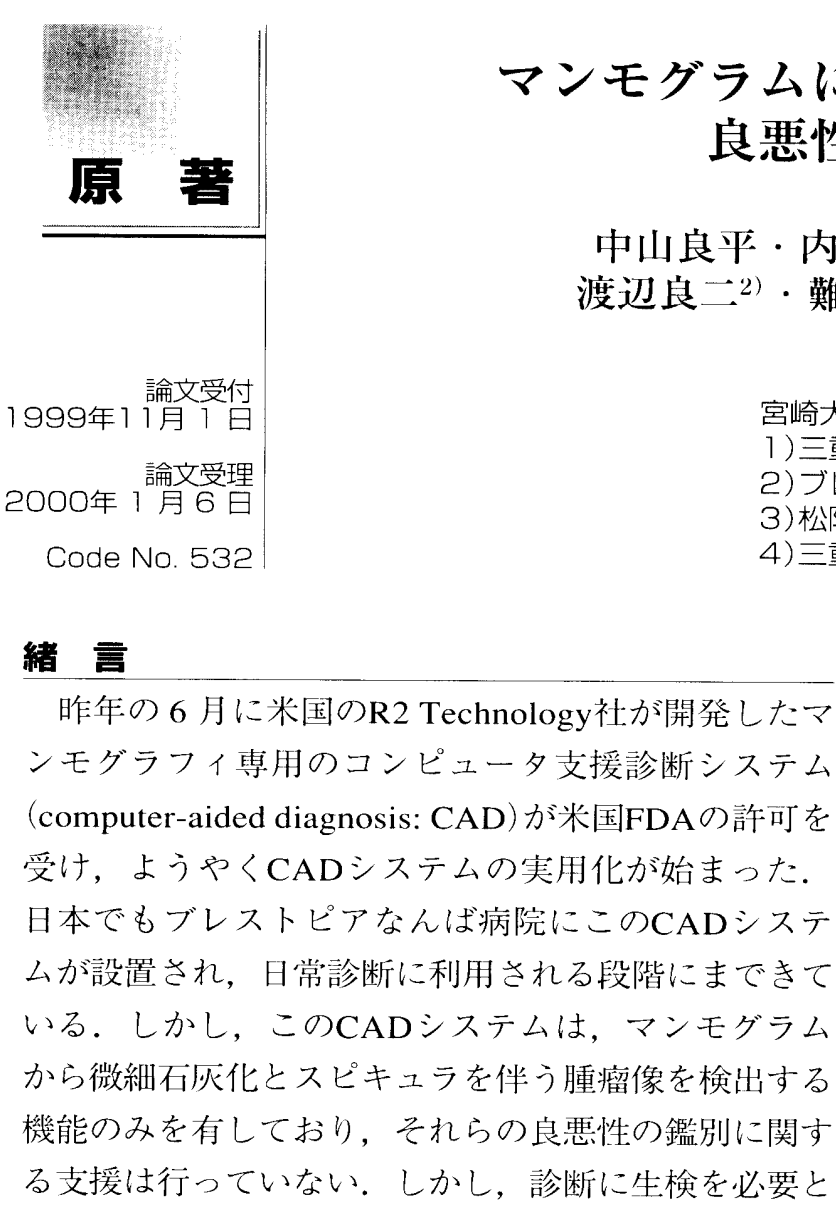

宮崎大学工学部情報システム工学科

1 ) 三重大学医学部付属病院医療情報部

2)ブレストピアなんば病院

3)松阪中央総合病院放射線科

4) 三重大学医学部放射線科

するような困難なケースにおいてて陽性予測度は15３0 \%と低く1.2)，良悪性の鑑別を支援するCADシステム の開発が求められている.

CADを良悪性の鑑別に応用するために多くの試み が行われてきた。たとえば，早い段階でこの分野の研 究を行ったShenらは個々の石灭化の形状に着目した三 つの特徽量を用いて良悪性鑑別を行っている37. Chan らは石灰化の濃度の変動も含めたいくつかの形状の特 徵とテクスチヤの特徵から識別に有効な特徵の組み合 わせを報告した ${ }^{4.5)}$.Jiangらは八つの特徵量と二ュー ラルネットを用いた鑑別システムを構築し，そのシス

\title{
Computerized Discrimination of Malignant and Benign Microcalcification Clusters on Mammograms
}

\section{RYOHEI NAKAYAMA, YOSHIKAZU UCHIYAMA, ISAMU HATSUKADE, KOJI YAMAMOTO, 1) RYOJI WATANABE, 2) KIYOSHI NAMBA, ${ }^{\text {) }}$ KAKUYA KITAGAWA, ${ }^{3)}$ and KAN TAKEDA ${ }^{4}$}

Department of Computer Science and Systems Engineering. Miyazaki University

1) Medical Informatics Section, Mie University School of Medicine

2) Breastpia Namba Hospital

3)Department of Radiology. Matsuzaka Central Hospital

4) Department of Radiology, Mie University School of Medicine

Received Nov. 11, 1999; Revision accepted Jan. 6, 2000; Code No. 532

\section{Summary}

This paper introduces a classification of clustered microcalcifications that is based on the weightedwavelet transform technique in digitized mammograms. The method uses three indicators of malignancy: (1) the standard deviation of the densities of individual microcalcifications within a cluster, (2) the coefficient of variation of their sizes within a cluster, and (3) the circularity of a cluster. The method was applied to the evaluation of malignancy in 62 microcalcification clusters selected as somewhat difficult cases from Breastpia Namba Hospital's patient files by an experienced mammographer. The results of the discriminant analysis using these indicators showed $85.3 \%$ sensitivity and $85.7 \%$ specificity. 
テムの性能部俩を行っている6.7!。これらの研究結果 は，CADによる骖断支嗳システム開発の可能性を十。

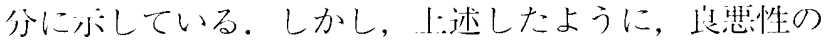
鑑㺫を文援するCADシステムとして阽床で使えるも のには大っていない。この場合，良琶性鑑别能力に優

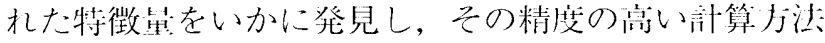
を確けするかが重荄な課題となる。本稿もこの点に焦 熟をあて書か狆ている。

1999售に仙成らは，重み付きウェーブレット解析手: 法を提条しため.9.彼らが提案した于法は，マンモグ ラムのけの微細们灰化陰影をその形状を保持しながら 選択们に强調する能打に優狄ている。このことは，鑑 別に用いる種々の特徽量の棓算精度が响トし，非”常に

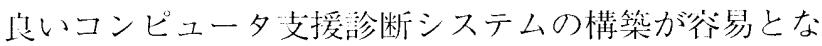
る叮能性が高い，過去に使わ狄た特徽㫣であっても， 胡算精度の问上によって非常によいシステムとなる问 能性がある。われわれはこの点に着日し，发些性の診 断が微妙で最も林難なタラス夕化した微絊们疢化に焦 点老絞って，そ玌らの良蚛性鑑别システムを作成し， 牛:検によって初めて診断が確定された診断の网難な35

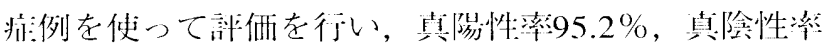
$78.6 \%$ という結果を得て，第1報としたは，その時鑑

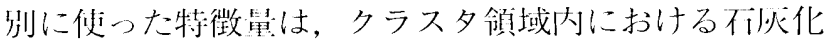

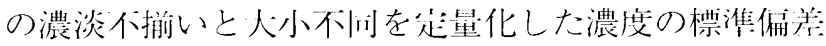
と大きさの变動係数，显びに不化の空間的な分仍を

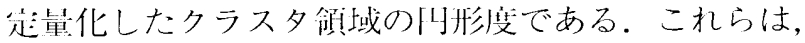

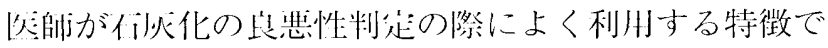
ある11.12!。

このシステムを䏘いて症例数を増やし，判别できな かーたケースを分析古るなかで，似必化の空間的な分 们の走莗化にはまだ多くの課題があることが明らかに なってきた。それは，第1報で使归した方法ではクラ

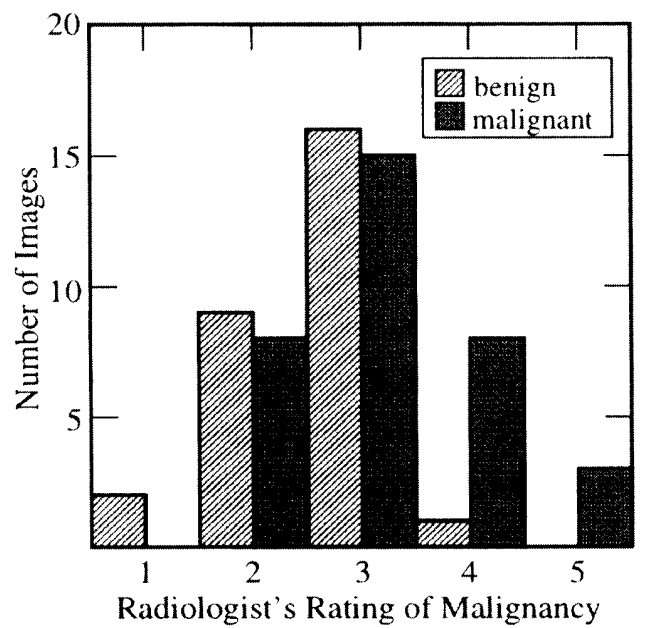

Fig. 1 Histogram of the radiologist's rating of the likelihood of malignancy in the clustered microcalcifications.
ス夕領域が偑々の不灰化除影の位㯰関係に強く依存し すぎるなど，システムの来軟性に弱い梷である。この 問題に対処するため，クラス夕領域の設望にモルフォ ロジ演算を追加して收是を加えた。また，濃淡不揃い の定星化に関しても，部收良を行っている。本稿は， 新しいシステムの紹介と，生検によって初めて獄断が 確起された獄断の村難な62怔例を䏘いたシステムの性 能評仙報告である。

\section{1. 試料と方法}

\section{1-1 対象画像}

ブレストピアなんば将院で拡大掫影された微細们灰 化クラス夕を伴うフィルム62枚を刘管に解析を行っ た。その内訳は呂性28症例，曹性34症例であり，廷热 性の診断は牛検により行われたものである。それらを

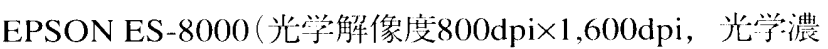
度レンジ3.3D）在用い空䦌分解能 $50 \mu \mathrm{m} / \mathrm{pixel}$, 濃度分 解能12bit (4,096階調)でディジ夕イズしたものを画像 データとして用いた。

これらの疾例に対して生検情報を知らされていない

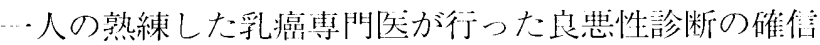
度をFig.1に亦す。造些性骖断の確信度の評起基淮 は，1：絶対良性，2：たぶん良性，3：患性の叮能性 を㑒定できない，4：たぶん恋性，5：絶対榓性，であ

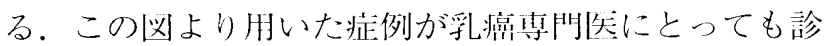
断の非常に困難な拝例であることが分かる。

\section{1-2 個々の石灰化の 2 值化}

在疢化陰影に対する特徽量を計算するには，最初に

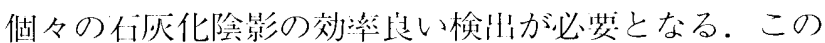
とき，非常に淡い微紐な石灰化陰影も検击できること が微細不扊化クラス夕の良些性鑑別には重琶である。 内叫らが提案した重み付きウェーブレット解析法で は，任意の人きさの咑证型形状のみを效率的に取り 出し強調することができる。その詳絊は，文献丈91に 譲るが，われわ机はまず，この重み付きウエーブレッ 卜解析によって句所、型形状を強調し, その後 2 值化

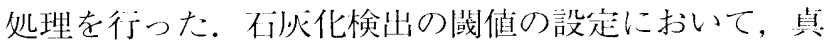
晹性候補を $100 \%$ 検出するように䦨值を低めに放定す ると偽陽性候補も検出される。本研究の甘的は做々の 特徽量の鑑別性能評価であるため，これら偽陽性候補 を手で削除し，良悪性鑑別の特徵量の抽出には真陽性 の们疢化陰影のみを扱うこととした。

\section{1-3 クラスタ領域の定義}

抢の抢のの不炏化の重心を中心に半径50pixel (1.35 mm相当)の回を描き，周囲の师と接すると间じ クラス夕に風すると仮起して，最初のクラス夕領域の 
初期値を決定する．第 1 報で提案した旧システ ム10)ではこの初期值を 最終のクラスタ領域と 定義していた。しか し, Fig.2bのように湾が できてしまうような症 例の場合, 視覚的判断 では円形と判断される ような状態であっても， 特徵量計算では線状と 判断されるケースがあ

る。これはクラス夕領域の決定が個々の石灰化陰影の 位置に強く依存しすぎていることによる，特徵量が個 々の石灰化の位置関係を反映することは一方で必要で はあるが，あまり敏感に反映することはシステムの柔 軟性の観点からは好ましくない．そこで新システムで

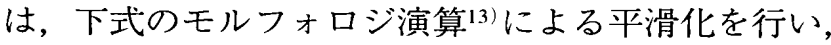
それをクラスタ領域と定義する(Fig.2c).

$$
X^{B}=\left(X \oplus B^{S}\right) \ominus B
$$

ここで，集合 $X$ は円に覆われた領域，構造要素Bは 半径30の円とする．また，集合 $X^{B}$ はクラスタ領域を示 す.

\section{1-4 特徵量の抽出}

新システムで用いる三つの特徵量はいずれも石灰化 の成因を考慮したものである，石灰化の成因はさまざ まであり，癌の石灰化に扮いてもいくつかの成因がみ られる。たとえば，ほとんどの癌の発生母地といわれ ているTDLU (terminal duct lobular unit) で発生した癌 細胞は乳管内で増殖延伸を続けていく，その際に，管 腔中心部の癌細胞の上うに血液により送られてくる酸 素や栄養分を周囲の癌細胞に吸収されてしまい壊死に 陥るものや，寿命で壊死に陷ってしまう癌細胞がでて くる。これら壇死に陥ったものが管腔中心部に集まり カルシウムが沈着して石灰化となる壊死型石灰化や腺 腔内に拄ける多量の分泌物や粘液の貯留，壊死物質の 浮遊などのうっ滞，析出が成因とされる分泌型石灰化 である。これらの石灰化は, 石灰沈着の程度, カルシ ウム含量の差が大きいうえ，乳癌が乳管内を進展した ため不整となった内腔を埋めている，そのため，石灰 化の濃淡差，大小差は幅広いものとなっている ${ }^{14.15)}$.

また，腺葉内の乳管の走行・分岐に一致して分布して いる，本手法では上述した石灰化の性質から，濃淡不 揃い，大小不同，クラスタ化した石灰化の空間的分布 の三つを良悪性鑑別の特徵量として選択した．以下に これら三つの特徵量の詳細な計算法を説明する.

\section{1-4-1 濃度の標準偏差 $(S D)$}

石灰化間の濃淡不揃いを計測するために，本手法で はクラスタ領域内に存在する石灰化の濃度值の標準偏 差を用いる．しかしながら，個々の石灰化の濃度值を どのように与えるかは難しい問題である．石灰化はさ まざまな容姿のものがあり，たとえば，1個の石灰化 の中でも濃淡不均一なもの, 淡く均一なもの, その中 央にのみ高い輝度値を持っているものなどが挙げられ る.このような石灰化に対して，単純に石灰化の全濃 度值の平均をその石灰化の濃度值として用いたなら ば，中央にのみ高い輝度值を持つ石灰化はその周りの 低い濃度値によって值が平均化されるため, 淡く均一 な石灰化との濃度值の差がみられなくなってしまう. そこで归システムでは，各石灰化の濃度值はそれぞれ の石灰化領域内において輝度値の大きいものから五つ の平均として与えた。しかし, 石灰化が存在する背景 領域の濃度值の影響によって，それぞれのクラス夕領 域間の石灰化コントラストにバラッキが存在すること も問題である。この問題に対して新システムでは，ウ エーブレット解析の部分再構成法を用いることで背景 領域の濃度值の除去を行い, 石死化コントラストのバ ラツキをなくすことにした。この方法は原画像をスム ージングすることによって得られる背景の大まかな変 動を原画像から除去することに等しい。このように旧 システムの計算法に改良を加えて得られた石灰化の濃 度值を $I_{k}$ とすると，濃淡不揃いを表す $S D$ の計算は次式 となる。

$$
S D=\sqrt{\frac{1}{N} \sum_{k=1}^{N}\left(I_{k}-\bar{I}\right)^{2}}
$$

ここで，Nはクラスタ内に存在する石灰化の個数， $\bar{I}$ は $I_{k}$ の平均とする.

\section{1-4-2 面積の変動係数 (CS)}

悪性腫瘍の場合, クラスタ内での石疢化除影の大き さがばらつくことが多い.そこで，人間の視覚的判断 に一致するように，このばらつきの度合いの定量化を 
行う。一般に，ばらつきの度合いを定量化する場合， 標準偏差がよく用いられているが，標準偏差ではクラ ス夕内に存在する石灰化の值積の平均に強く依存する ことが問題である。たとば石死化クラス夕C1と， C1内の各石疢化の面積を $T$ 倍 $(T>1)$ した石症化クラス 夕C2があった場合，人間の視覚的判断ではクラス夕 C1，C2における石疢化㓌影の大きさのばらつきは等 しいと判断されるが，特徽量の定量化を標準偏差によ り行うとC2の值がC1の倍となり，C2がC1よりばらつ きが大きいと判断され，人間の視覚的判断に一致しな くなる。そこで，大きさのばらつきの度合いを不扊化 㓌影の面積の変動係数によって定量化し, 特徵量とし て使用する。ここで, 個々の石灰化㓌影の面積 $A_{k}$ は 2 值画像におけるその石疢化陰影の画素数とする。この とき面積の変動係数CSは次式で与えられる。

$$
C S=\frac{1}{\bar{A}} \sqrt{\frac{1}{N} \sum_{k=1}^{N}\left(A_{k}-\bar{A}\right)^{2}}
$$

ただし，Nはクラスタ内に存在する石灰化㓌影の個 数, $\bar{A}$ は $A_{k}$ の平均とする.

\section{1-4-3 クラスタ領域の円形度 $(C M)$}

悪性腫瘍による石灰化が乳管に沿って成長していく ことから，クラスタの形状も一つの有効な特徽量とな る. 形状の定量化には種々の試みがなされてきたが, ここでは，12個の指標を用い师形度を求めることにし
た。まず，クラスタ領域の重心からクラスタ領域を囲 む最小の長方形の境界までの 4 方向の距離を最初の 4 個の指標とし, 残りの 8 個の指標はクラス夕領域の重 心からクラス夕領域の端までの 8 方向の距離とする。 これら12個の指標の標準偏差を为いて円形度と先義し た場合，1-4-2と同様に，クラス夕領域の大きさに依 存する問題が生じる. そのため12個の指標の変動係数 $C M$ をラスタ領域の四形度と定義する(Fig.3).

$$
C M=\frac{1}{\overline{S I}} \sqrt{\frac{1}{12} \sum_{k=1}^{12}\left(S I_{k}-\overline{S I}\right)^{2}}
$$

ここでSIkは各指標， $\overline{S I}$ は12個の指標の平均を示す。 もし，クラス夕領域が円形であれば12個の指標は同じ 值となり変動係数はゼロとなる。しかし，クラス夕領 域が複雑(線状，分枝状)であれば，指標值の大小の羘 が大きくなり変動係数の值が大きくなる。

\section{2. 結 果}

微細石疢化クラスタ62症例に対して，良悪性鑑別に 用いる特徽量の計算を行った。Fig.4a，bはそれぞれ濃 度の標準偏差と面積の変動係数の二次元空間での分 布，およびクラス夕領域の円形度の分布を示したもの である。一般に，良性石疢化クラス夕と悪性石疢化ク ラスタの間にかなりの重複がみられる。しかしなが ら，良性石疢化クラス夕，慗性石疢化クラスタそれぞ れに分布の偏りが確認できる。 たとえば，Fig.4aにおいて良性不 灰化クラス夕は左下に分布する 傾向がみられ，悪性石疢化クラ ス夕は右上に分布する傾向がみ られる。このことは，悪性石扊 化クラスタに濃淡不揃い, 大小 不同が多くみられることを示 し，1-4で述べな悪性石疢化クラ スタの性質と一致することが分 かる。またFig.4bに関しては良性 石灰化クラスタが下に，悪性石 灰化クラスタが上に分布する傾 向がみられ，悪性石疢化クラス 夕が癌細胞の乳管内進展に伴 い，線状または分枝状を示す性 質と一致している.

統計的な性質を調べるために SPSS統計パッケージソフトウエ ア16)を用いて判別分析を行っ た. Table 1 は平均值と標準偏 差, Table 2 はそれぞれの特徵量 が良性，悪性のグループごとで

Fig. 4 Diagrams of the distributions of malignant and benign clustered microcalcifications according to three features. 
Table 1 Simple statistics (mean \pm standard deviation).

\begin{tabular}{l|c|c|c}
\hline & SD & CS & CM \\
\hline Benign & $146.78 \pm 67.73$ & $57.93 \pm 15.83$ & $11.99 \pm 7.06$ \\
\hline Malignant & $214.63 \pm 93.31$ & $79.91 \pm 16.84$ & $20.98 \pm 8.82$ \\
\hline All data & $183.99 \pm 88.88$ & $69.98 \pm 19.65$ & $16.92 \pm 9.19$ \\
\hline
\end{tabular}

Table 2 Tests for univariate equality of group means.

\begin{tabular}{c|c|c|c}
\hline & Wilks' lambda & $F$ & Significance \\
\hline SD & .853 & 10.32 & .002 \\
\hline CS & .685 & 27.62 & .000 \\
\hline CM & .759 & 19.05 & .000 \\
\hline
\end{tabular}

Table 3 Pooled within-group correlation matrix.

\begin{tabular}{c|c|c|c}
\hline & SD & CS & CM \\
\hline SD & 1.000 & 0.161 & -0.053 \\
\hline CS & 0.161 & 1.000 & 0.155 \\
\hline CM & -0.053 & 0.155 & 1.000 \\
\hline
\end{tabular}

Table 5 Standardized discriminant function coefficient.

\begin{tabular}{c|c}
\hline \hline SD & .396 \\
\hline CS & .610 \\
\hline CM & .558 \\
\hline
\end{tabular}

異なっているか否かの検定結果である．Table 2 にお いてWilksのLambdaは各特徵量に㧈ける良性と琹性の グループ間の差を示す指標であり，またF值はそれぞ れの特徵量を単体で使ったときの識別能力の指槽であ る。この表からこれら三つの特徵量のなかで，CSが 最も大きな識別能力を持っていることが分かる．逆に $S D$ は識別能力としては最も小さなものであるが，そ れでも 2 グループ間で有意に異なっているので識別能 力は低くはないと予想される。

Table 3はそれぞれの特徵量間の独立性を知るため に，各特徽量において良性，悪性の二つのグループを 一つにまとめ相関を調べたものである。この表から， 他の特徵量との独立性は $C M$ が最も強く, $C S$ と $S D$ との 間には弱い相関があることが認められる。しかし，こ の 3 変数の間に特に強い相関がないことから，鑑別の 特徵量として良い性質を持っていることが分かる。

判別に寄与する特徵量の相対的重要性を検討するた めステップワイズ判別分析を行った。その結果を Table 4 6 に示寸. Table 4 は有用な特徵量 (説明変数) を精選するため变数増加法による变数 (特徽量) 選択の 結果である. 変数増加法とは判別に最も有効な変数か ら順に判別式に取り入れていき，判別精度の向上がみ られない変数の除去を行うものである. Table 4 に拉 いて最も識別能力の低い $S D$ まで判別式に取り入れて も判別精度の向上がみられるため，今回用いた三つの 特徵量すべてが判別に有効であることが認められる.
Table 4 Wilks' lambda.

\begin{tabular}{c|c|c|c|c|c|c}
\hline Step & Variable & Lambda & F & F-ratio 1 & F-ratio 2 & Significance \\
\hline 1 & CS & .685 & 27.62 & 1 & 60.0 & $2.07 \mathrm{E}-06$ \\
\hline 2 & CS, CM & .597 & 19.94 & 2 & 59.0 & $2.43 \mathrm{E}-07$ \\
\hline 3 & CS, CM, SD & .557 & 15.40 & 3 & 58.0 & $1.75 \mathrm{E}-07$ \\
\hline
\end{tabular}

Table 6 Percentage of cases classified correctly.

\begin{tabular}{c|l|c|c|c}
\hline \multicolumn{2}{c|}{} & \multicolumn{2}{c|}{ Diagnosis } & \multirow{2}{*}{ Total } \\
\cline { 3 - 5 } \multicolumn{1}{c|}{} & Benign & Malignant & \\
\hline \multirow{4}{*}{ Patient } & Benign & 24 & 4 & 28 \\
\cline { 2 - 5 } & Malignant & 5 & 29 & 34 \\
\cline { 2 - 5 } & Benign & $85.7 \%$ & $14.3 \%$ & $100.0 \%$ \\
\cline { 2 - 5 } & Malignant & $14.7 \%$ & $85.3 \%$ & $100.0 \%$ \\
\hline
\end{tabular}

Table 5 においてはCSの判別係数の值が大きいことか ら，CSが判別に最も寄与していることが分かる。ま た, Table 6 から分かるように, 新システムでは, 真 陽性率 $85.3 \%$ (34症例中 29 症例), 真㓌性率 $85.7 \%$ (28 症例中24症例)という結果が得られた。

\section{3. 考 察}

\section{3-1 旧システムとの比較}

良悪性を鑑別するため，旧システムも新システム も，石灰化陰影の濃度の不揃い，大きさの不揃い，ク ラス夕領域のけ形度の三つの特徽の定量化を行ってい る。濃度について旧システムでは, 個々の石灭化院影 の濃度值として，それぞれの石灰化領域のなかから上 位 5 点を取り出し, その平均值をそれぞれの石灰化陰 影の濃度值とし，クラスタ内での濃度值の標準偏差を クラスタ内での濃度の変動を表す指標としていた。ま た，旧システムではクラス夕領域の設定でモルフォロ ジ演算は行わず，個々の石灰化陰影の位置に強く依存 した形となっていた。これらのことが統計的にはどの ような違いとなって現れるかを知るため，同じ症例に 対して旧システムでの分析を行った結果，F值(有意確 立)はCMが4.518(0.038)，SDが18.025(0.000), CSが $27.619(0.000)$ となり, 特にCMについては識別能力が 


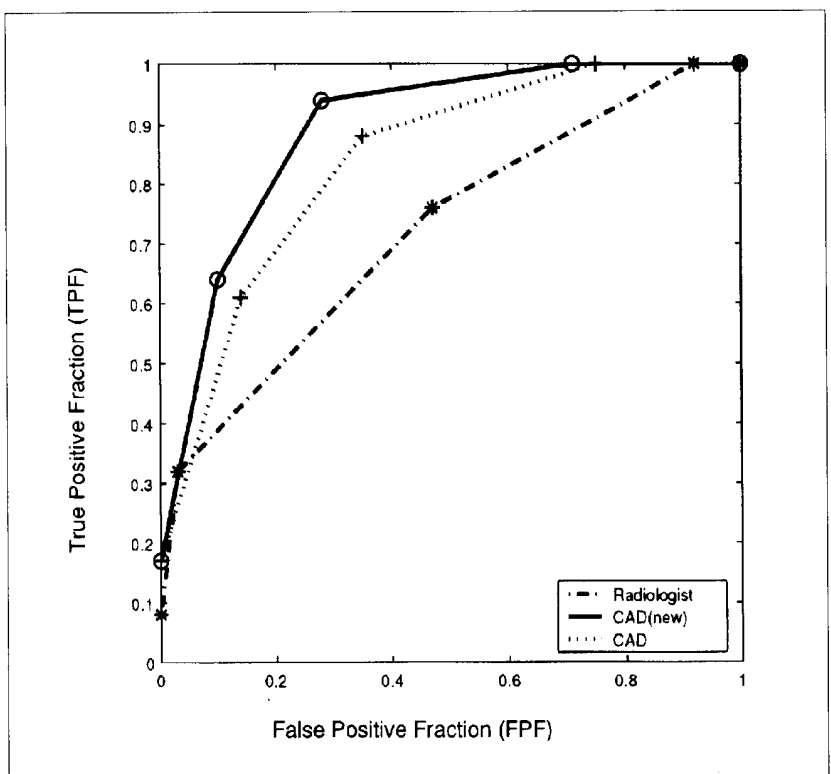

Fig. 5 Results of ROC analysis.

弱いことが分かった。また，特徵量間の相関もCSと $S D$ の間で 0.261 と高い。これらの特徵量を用い新シス テムと同様に，ステップワイズ判別分析を行った結 果， $C M$ はF值が小さすぎて判別には寄与せず，CSと $S D$ ので判別を行う結果となった。 その判別結果は 真陽性率79.4\%(34症例中27例)，真陰性率82.1\%(28 症例中23例) となり新システムの識別能力の方が上ま っている。しかし，SDのF值をみると，旧システムの 方が新システムの計算法より少し大きいため，より高 い識別能力を持つ結果となった。旧システムのSDで は濃度変動の計算に原画像の濃度值をそのまま用いて いるため背景濃度值も含まれた形となっている。この ことは，1-4-1で説明したように濃度変動を表す指標 としては物理的には正しくない。このため, 新システ ムではスムージング画像を背景画像として石灰化の濃 度值から差し引き計算を行ったのだが，スムージング 画像には石疢化陰影の影響が入っているため，引きす ぎる欠点がある。このことが，結果に影響したのであ ろう。この点に関しては新システムにさらに改良の余 地が残されている。

\section{3-2 ROC解析}

本論文で提案した新システムの62症例における良悪 性鑑別実験の結果は，真陽性率 $85.3 \%$ ，真陰性率85.7 \%であった。しかし，これらの成績だけでは単純にシ ステム性能を示しているとはいえない.そこでROC解 析 $^{17)}$ に基づく性能評価を行った.フィルムの病院外へ の持ち出しが不可能であったため, 乳癌専門医には各 症例に対し，Microsoft Power-Point Viewerを用いて，
微細石灰化クラス夕の存在する拡大撮影されたフィル ム全体像とそのクラス夕部分の拡大像を与えた。ただ し，拡大像は石灰化が明瞭となるように濃度階調の調 整を行っている。これらの画像を基に62症例に対し て，一人の熟練した乳癌専門医に五つの確信度の評定 基準に区分してもらった。複数の乳癌専門医に依頼し ていたが，一人の専門医しか回答を得られなかったた め, 今回は一人の専門医の確信度結果を用いた (Fig.1)。この確信度の結果よりFig.5にROC曲線を示 す。実線は新システム, 点線は旧システム, 鎖線は乳 癌専門医を表している。このROC解析の結果より，新 システムは旧システムよりも性能が向上していること が分かる。また，本手法の性能が乳癌専閒医の診断の 確信度を上回っている。しかしながら, 乳癌専門医は CRT上での診断であったため，診断がより困難なもの となったかもしれない.

ところで，本手法でわれわれが用いた特徵量は従来 から研究されてきた特徽量を利用，もしくは改良を加 えたものである。それらの特徵量を用い，鑑別の非常 に困難な症例に対して高い鑑別性能を得られたことに 関して二つのことが考えられる。一つはマンモグラム 上の小さなら状の部分だけを強調・抽出できる重み付 きウェーブレット変換を用いたことである。この変換 を用いて評価された特徴量は個々の石死化の性質を正 確に示すと考えられる。もう一つは，新システムでは クラスタ領域が個々の石灰化㓌影の位置関係に強く依 存しすぎていた問題に対処するため，モルフォロジ演 算を追加して改良を行ったことである。これによりク ラス夕領域の円形度に大幅な改善がみられ，人間の視 覚的判断と同じような特徽量を得ることができるよう になった。これらのことより, システムの出力結果を 医師が診断に用いる特徴量の一つとすることで診断支 援として有効であるといえる。

\section{4. 結 語}

本稿では，クラスタ化した微細石灰化の良悪性鑑別 のための特徴の正確な抽出および診断レベルでのCAD の可能性に重点をおいて検討を行った.すなわち，ウ エーブレット解析に基づいた方法を用いることで医師 によって指摘された三つの特徵の正確な抽出を行い, 良悪性の鑑別が非常に困難な62症例に対して鑑別実験 を試みた。この結果，真陽性率 $85.3 \%$ ，真陰性率85.7 \%を得た。また，ROC解析による本システムの評価で は本システムの性能が放射線科専門医の診断の確信度 を上回ることも確認した。これらの結果は，本論文で 提案した微細石灰化クラスタの良悪性識別システムの 有効性を十分に示している。 


\section{参考文献}

1) Adler DD and Helvie MA: Mammographic biopsy recommendations. Current Option in Radiology, 4, 123-129, (1992).

2) Kopans DB: The positive predictive value of mammography. Am J Roentgenol, 158, 521-526, (1991).

3) Shen L, Rangyyan RM, and Desautels JEL: Application of shape analysis to mammographic calcifications. IEEE Trans Med Imaging, 13 (2), 263-274, (1994).

4) Chan HP, Sahiner B, Petrick N, et al.: Computerized classification of malignant and benign microcalcifications on mammograms: Texture analysis using an artificial neural network. Phys Med Biol, 42, 549-567, (1997).

5) Chan HP, Sahiner B, Lam KL, et al.: Computerized analysis of mammographic microcalcifications in mammographical and texture feature spaces. Med Phys, 25 (10), 2007-2019, (1998).

6) Jiang Y, Nishikawa RM, Wolverton DE, et al.: Malignant and benign clustered microcalcifications: Automated feature analysis and classification. Radiology, 198, 671-678, (1996).

7) Jiang Y, Nishikawa RM, Schmidt RA, et al.: Improving breast cancer diagnosis with computer-aided diagnosis. Acad Radiol, 6, 22-33, (1999).

8) Uchiyama $Y$ and Yamamoto $\mathrm{K}$ : Enhancement of microcalcifications in mammograms using dyadic wavelet analysis. Med Imag Tech, 17 (3), 261-271, (1999).
9) 内山良一, 中山良平, 山本皓一, 他：ウェーブレット解析 を用いた乳房X線写真に挹ける微細石扊化クラスタの検 出. 第 9 回コンピュータ支援画像診断学会大会, 京都, 1999-11, コンピュータ支援画像診断学会, 第 9 回コンピ ユー夕支援画像診断学会大会論文集，29-30，(1999).

10) Nakayama R, Uchiyama Y, Yamamoto K, et al.: Discrimination of malignant and benign microcalcification clusters on mammograms. コンピュー夕支援画像診断学会論文誌, 3(3), (1999).

$11)$ Kopans DB: Breast Imaging, 2nd edition. Lippincott-Raven Publishers, (1998).

12) 森本忠興, 笹 三徳：検診のためのマンモグラフィ・アト ラス、デジタルプレス, 東京, (1996).

13）小畑秀文：モルフォルジー，コロナ社，東京，(1996）.

14）(社) 日本医学放射線学会/(社) 日本放射線技術学会マンモグ ラフィガイドライン委員会：マンモグラフィガイドライ ン. 医学書院, 東京, (1999).

15) 岩瀬拓士, 吉本賢隆, 渡辺 進, 他: 非触知石灰化病变の 診断一石灰化の形態とその病理組織像より一。乳癌の臨 床, 9(3)，393-402，(1994).

16) SPSS Professional Statistics 6.1, Marija J. Norusis/SPSS inc.

17）藤田広志, 志村一男, 白石順二, 他：ROC解析の基礎と応 用. 放射線医療技術学丵書 8 , 日本放射線技術学会出版委 員会，(1994）。

Fig. 1 乳癌専門医による良悪性診断の確信度のヒストグラム。

Fig. 2 クラス夕領域の定義.

Fig. 3 12指標の例.

Fig. 4 三つの特徴量の分布.

Fig. 5 ROC解析の結果.

Table 1 基本統計量 (平均值土標準偏差).

Table 2 グループ平均の差の検定.

Table 3 プールされたグループ内相関行列.

Table 4 Wilks Lambda.

Table 5 標準化された正準判別関数係数.

Table 6 分類結果. 